\title{
Entrepreneurship Training Programme in Universities and Graduates' Productivity in South-South Nigeria
}

\author{
Ngozika A. Oleforo ${ }^{1}$, Dominic Edema Oko $^{2} \&$ Eno G. Akpan ${ }^{1}$ \\ ${ }^{1}$ Department of Curriculum Studies, Educational Management and Planning, University of Uyo, Uyo, Nigeria \\ ${ }^{2}$ Early Childhood and Special Education, University of Uyo, Uyo, Nigeria \\ Correspondence: Ngozika A. Oleforo, Department of Curriculum Studies, Educational Management and \\ Planning, University of Uyo, Uyo, Nigeria. Tel: 234-803-709-5841. E-mail: ngozikanz1@yahoo.com
}

\author{
Received: November 19, 2012 Accepted: November 20, 2012 Online Published: July 1, 2013 \\ doi:10.5539/ies.v6n7p260 \\ URL: http://dx.doi.org/10.5539/ies.v6n7p260
}

\begin{abstract}
Entrepreneurial training programme has to do with acquiring relevant skills in which an individual has to be sensitized, motivated and guided to achieve self-reliance and self employment. The paper examined the relevance of entrepreneurial training programme in the universities to graduates' productivity. Three null hypotheses were formulated. A sample size of 1200 graduates was randomly selected from the South-South Geo-Political Zone in Nigeria. The instrument used for the study was Entrepreneurial Training Programme in the Universities and Graduates Productivity Questionnaire (ETPUGPQ). The instrument was validated with the help of three experts in vocational education. The corrected version was subjected to the test of reliability using Cronbach Alpha, and the reliability co-efficient stood at 0.85 justifying the use of the instrument. The data obtained were analyzed using Multiple Linear Regression at 0.05 alpha levels. It was found that entrepreneurial training programme in the universities is significantly relevant to graduates' productivity. Therefore, it was concluded and recommended that the government and National University Commission (NUC) should make it compulsory for faculties offering professional courses to encourage students participation in practical works. Also it was recommended that Entrepreneurship Education curriculum should be developed to cater for the vast changing needs of the labour market.
\end{abstract}

Keywords: Entrepreneurial training programme, Entrepreneurship Education curriculum

\section{Introduction}

Education is the bedrock for national development in Nigeria in terms of economy, science and technology, social and cultural development. It is an instrument for human capital development. Accordingly, universities and other skill development institutions are designed to train individuals, equip them with skills, knowledge, attitudes and values that will enable them to contribute to national development. Nigeria has a lot of natural and human resources and has invested significantly to set up universities with many facilities. There are many states, federal and private universities in the country. However, one of the challenges that youths in the country contend with is unemployment. The graduates from the universities are said to be unproductive. This has led to a situation where those who are lucky to be employed are trained and retrained by their employers. Oladapo and Ike (2010) supported this fact by stating that in Nigeria when locally trained engineers, for example, are employed, they are usually made to undergo training within the company and sometimes outside the country before they are assigned any significant roles to perform.

Adequate entrepreneurship training is believed to be the only solution to equipping the students with skills that can make them productive. Kauffman Foundation (2009) defined entrepreneurship training as the process of providing individuals with knowledge and skills to recognize opportunities that others have over-looked to have insight, self esteem and knowledge to act where others have hesitated. It includes institution of opportunity recognition marshalling resources in the face of risk and initiating a business venture. According to Madumere-Obike and Abraham (2008), entrepreneurship training enhances creativity in technical and vocational skills and inculcates in the individuals the abilities that are necessary for them to be self-reliant through formal education. One of the objectives of entrepreneurship training is to provide students with skills and motivations in order to enhance entrepreneurial endeavour in any enterprise of their choice. Etuk and Ekpo (2008) affirmed that: 
Entrepreneurship brings together the factors of production, human, land, labour, capital to make products for public development and consumption. It incorporates the willingness and ability of a person to explore and exploit investment opportunities, establish and manage successful business enterprise. Thus, the re-designed programmes will equip economic ventures on their own. This way, unemployment will be surmounted, as every graduate will be involved in a productive venture that will yield income and thus alleviate poverty. (p.57)

Oluruntoba (2010) stated that entrepreneurship training focuses on development, understanding and capacity building for pursuit of entrepreneurial behaviours, skills and attitudes in widely different contexts. In the United States of America, there are formal entrepreneurship training programmes that turn out tens and thousands of prepared, motivated entrepreneurs each year. Moreover, Oluruntoba enjoined that when entrepreneurship training is incorporated into an education system, the skills acquired would benefit the society and individuals.

In the words of Fluitman and Haan (2002), traditional apprenticeship enhances the development of useful skills in young people particularly in West African countries. Fluitman and Haan also pointed out that in Gambia, a vast majority of people who could not find employment had created their own jobs by establishing micro-enterprises that produce essential goods and provide needed services to a large number of customers. This means entrepreneurship training given to students can make them become productive. Productivity has to do with graduates' performance after leaving the universities. Peretomode (2003) viewed performance as any action exhibited by an individual which identifies him or her as a member of a group.

The European Union (2002) noted that the main objective of teaching entrepreneurial education especially to undergraduate students is to increase students' awareness of self-employment as a career option (the message being that you can become not only an employee, but also an entrepreneur); promoting the development of personal qualities that are relevant to entrepreneurships, such as creativity, risk-taking and responsibility, and providing the technical and business skills that are needed in order to start new venture.

As noted by Kurako (2003), it has been a decision by many tertiary institutions in the United States, Europe, East Asia and Latin America to design and implement relevant entrepreneurship teaching programmes in their curriculum. For instance, in American Higher Education, the objectives of entrepreneurship education are:

- To become an expanding area of American college learning

- To become a basic part of what University themselves do

- Meet many of the goals of a quality American undergraduate education

- In fact it is mandatory for all American universities to clearly indicate in their undergraduate programme the type of entrepreneurship programme to be provided.

In Africa, much is yet to be done in this regard. As reported by Isaac, Visser, Friedrich and Brijlal (2007), entrepreneurship education in South Africa, started as far back as 1994 through a national curriculum for grade R-9. In Nigeria, entrepreneurship education especially at the university level is a recent development. By and large, entrepreneurship education in Nigerian Universities is coming at a time when the country is facing graduate unemployment. In fact, National Universities Commission (NUC) has gradually made it mandatory for Universities in Nigeria especially, the new ones to include entrepreneurship education in their undergraduate curriculum.

McClelland (1962) emphasized in his achievement motivation theory that the purpose of entrepreneurship training is to help people to develop strong achievement motivation which tends to drive people to become entrepreneurs. When graduates acquire skills, they can become self reliant and self employed; and this would reduce the rate of unemployment. The major concern of education therefore is to make man to live and function effectively in the society. In other words education should be made functional to meet the values of man as entrepreneurial and to produce job creators and not job seekers (Madumere-Obike \& Abraham, 2008).

Osuwa (2006) opined that the current wave of youth restiveness in Nigeria is a typical example of the result of unemployment. Entrepreneurship training in disciplines such as Engineering, Fine Arts, Technology Education, Home Economics, among others can bring about students acquisition of skills which would make them self-reliant and productive in their jobs.

The problem of entrepreneurship training is linked to factors such as lack of facilities, equipment, human resources and most importantly irrelevant curriculum and lack of practical experience. In 2006, the Federal Government of Nigeria directed that entrepreneurship training be incorporated as a mandatory component of all programmes run in our tertiary institutions (Rufa, 2010). The purpose of any entrepreneurial curriculum is to 
equip students with skills that would make them able to create wealth in the era of mass unemployment (Amaewhale, 2007; Nwangwu, 2007). The curricula for entrepreneurship training programme in the universities should be student-centred and emphasis should be on vocational and technical skills development. In other words, the university curriculum should adopt integrated approach, where a section is set aside mainly for practical training which would make students self-reliant especially in vocational courses.

According to Ekong and William (2006), the curriculum should promote self-initiative learning involving the whole person of the learner, and that the curriculum should be designed to make students acquire relevant entrepreneurial skills. Such curriculum will make them to be productive.

On the practical experience by students, it is obvious that the students do not gain enough experience due to resources problem such as inadequate equipment, laboratory facilities, infrastructures, and funds. This explains why most of the professional trained graduates are not productive. For Nigerian graduates to be productive there is need for adequate provision of facilities and equipment such as tools, machines, computer system and so on, since entrepreneurship training is practical oriented. Kiod (1977) emphasized that students who are able to practicalise learning are more productive than those exposed to only the theoretical learning.

Using engineering as an example, Oni in Oladapo and Ike (2010) suggested that Nigerian trained engineers can only be productive if institutional framework and policy environment are appropriately designed. However, the study by Oladapo and Ike on links between engineering training programmes in tertiary institutions and graduates' productivity in Nigeria, found that Nigerian Engineering curricula are too loaded with theories and rigid, and that the content of training had little relevance to employment.

In Nigeria, there is still the notion that the curricula of many programmes offered in the universities are irrelevant with regard to changes coming up in the society, and that poor quality and inadequate infrastructure and equipment contribute to graduate students not acquiring practical skills needed by the labour market. This study therefore is designed to ascertain the relevance of entrepreneurship training programmes offered in Nigerian universities to graduates productivity.

\section{Statement of the Problem}

The society, the government and individual rest their hope on education for individual and national development. Education that students receive does not seem to equip them with skills that would make them relevant to the society, thereby resulting into graduates' unemployment. Graduates from the universities are said to be unemployable, and where they are employed, the employers need to train and retrain them again before they are fully absorbed into jobs. On the other hand, where these graduates are employed without training, they appear to be unproductive. All these have been attributed to poor funding, lack of space, equipment, tools, human resources and most importantly irrelevant curricula and poor practical work experience. Therefore, the fundamental problem of this study is to find out if entrepreneurship training in the universities has any relevance to graduates productivity.

\section{Purpose of the Study}

The purpose of the study was to ascertain the relevance of entrepreneurial training programme in the universities to graduates' productivity in South-South Nigeria. Specifically, the study sought to:

1) Determine the relevance of entrepreneurial contents of university curricula to graduates' productivity.

2) Examine the relevance of practical experience acquired in the university entrepreneurship training programme to graduates' productivity.

3) Determine whether entrepreneurial contents of university curricula and practical experience acquired in the university entrepreneurship training programme jointly contribute to graduates' productivity.

\section{Hypotheses}

The following null hypotheses were formulated to guide the study:

1) Entrepreneurial contents of university curricula are not significantly relevant to graduates' productivity.

2) Practical experience acquired in the university entrepreneurship training programme is not significantly relevant to graduates' productivity.

3) There is no significant joint contribution of entrepreneurial contents of university curricula and practical experience acquired in the university entrepreneurship training programme to graduates' productivity. 


\section{Methodology}

The study employed the descriptive survey design to gather data to examine the relevance of entrepreneurial training programme in the universities to graduates' productivity in South South Zone of Nigeria. The area of the study was the South South Zone of Nigeria made up of six states: Akwa Ibom, Bayelsa, Cross River, Delta, Edo and Rivers. The population consisted of 9,072 NYSC members in year 2011/2012 Batch A in the six states. The sample size consisted of 1,200 NYSC members randomly selected in the six states for the study.

The research instrument, Entrepreneurial Training Programme in the Universities and Graduates Productivity Questionnaire (ETPUGPQ), was designed by the researchers for data collection. The instrument was a four-point rating scale with the following response options:

$\begin{array}{ll}\text { Strongly Agree (SA) } & -4 \text { points } \\ \text { Agree (A) } & -3 \text { points } \\ \text { Disagree (D) } & -2 \text { points } \\ \text { Strongly Disagree } & -1 \text { point }\end{array}$

To ascertain the validity of the instrument, the items were critically examined by three experts in Vocational Education for its face validity. The reliability of the instrument was tested on 30 NYSC members in the states that did not take part in the main study. Cronbach alpha was used in determining the reliability of the instrument. Cronbach alpha enabled the assessment of the internal consistency of the instrument which options were strongly agree, agree, disagree and strongly disagree. The reliability co-efficient stood at 0.85 ; which was considered high enough for the use of the instrument. Data collected was analyzed using Multiple Linear Regression at 0.05 alpha levels.

\section{Results}

Hypothesis 1: Entrepreneurial contents of university curricula are not significantly relevant to graduates' productivity.

Table 1. Regression Analysis showing Relevance of Entrepreneurial Contents of Curricula to Graduates' Productivity

\begin{tabular}{lllll}
\hline Model & \multicolumn{2}{l}{ Unstandardized Coefficients } & Standardized Coefficient & t \\
\cline { 2 - 4 } & B & Std Error & B eta & \\
1 (constant) & 7.538 & .492 & & 15.320 \\
Curricula Contents & 1.142 & .029 & .714 & $39.225^{*}$ \\
\hline
\end{tabular}

*Significant at .05 alpha level, $\mathrm{t}$ critical $=2.04$

Table 1 shows that a coefficient of 1.142 was obtained for the relevance of entrepreneurial contents of university curricula to graduates productivity in the linear regression model. The calculated t-value of 39.225 at .05 alpha level is greater than the critical t-value of 2.04. Therefore the null hypothesis is rejected. This means that entrepreneurial contents of university curricula are significantly relevant to graduates' productivity.

Hypothesis 2: Practical experience acquired in the university entrepreneurship training programme is not significantly relevant to graduates' productivity.

Table 2. Regression Analysis showing Relevance of Practical Experience to Graduates' Productivity

\begin{tabular}{lllll}
\hline Model & \multicolumn{3}{l}{ Unstandardized Coefficients } & Standardized Coefficient \\
\cline { 2 - 4 } & B & Std Error & B eta & t \\
1 (constant) & 7.538 & .492 & & 15.32 \\
Practical experiment & .326 & .031 & .194 & $10.64 *$ \\
\hline
\end{tabular}

*Significant at .05 alpha level, $t$ critical $=2.04$ 
Table 2 reveals that a coefficient of .326 was obtained for the contribution of practical experience to graduates productivity in the linear regression model. A calculated t-value of 10.640 was also obtained at .05 alpha level which is greater than the critical t-value of 2.04. The null hypothesis is rejected. Hence, practical experience acquired in the university entrepreneurship training programme is significantly relevant to graduates' productivity.

Hypothesis 3: There is no significant joint contribution of entrepreneurial contents of university curricula and practical experience acquired in the university entrepreneurship training programme to graduates' productivity.

Table 3. Multiple Linear Regression Analysis Result on Joint Contribution of Curricula Relevance and Practical Experience to Graduates' Productivity

\begin{tabular}{lllll}
\hline Model & Sum of Squares & Df & Mean Square & F \\
\hline 1 Regression & 22885.372 & 2 & 11442.686 & $1104.046^{*}$ \\
Residual & 12406.087 & 1197 & 10.364 & \\
Total & 35291.459 & 1199 & & \\
\hline
\end{tabular}

$*$ Significant at .05 alpha level, $\mathrm{R}=0.805, \mathrm{R}^{2}=0.648, \mathrm{~F}$ critical $=3.09, \mathrm{~N}=1200$

Table 3 shows the analysis of joint contribution of entrepreneurial contents of university curricula and practical experience acquired in the university entrepreneurship training programme to graduates productivity using Multiple Linear Regression. The coefficient of determination value $\left(\mathrm{R}^{2}\right)$ of 0.648 was obtained which shows that $64.8 \%$ of the total variation in graduates' productivity was attributed to joint contribution of entrepreneurial contents of university curricula and practical experience acquired in the university entrepreneurship training programme. The $\mathrm{F}$ calculated value of 1104.046 was obtained at 0.05 alpha level. Hence the null hypothesis is rejected, meaning that there is a significant joint contribution of entrepreneurial contents of university curricula and practical experience acquired in the university entrepreneurship training programme to graduates' productivity.

\section{Discussion}

The findings reveal that in Table 1 the coefficient of 1.142 was obtained for the relevance of entrepreneurial contents of university curricula to graduates productivity, and the calculated t-value was 39.225 which was greater than the critical t-value of 2.04 at 0.05 alpha levels. This implies that entrepreneurial contents of university curricula significantly contribute to graduates productivity. This is therefore in line with the views of Ekong and William (2006) that the curriculum should promote self-initiative learning involving whole person of the learner, that such curriculum should be designed to make students acquire relevant entrepreneurial skills and that such curriculum will make them to be productive. This also confirms the view of Amaewhale (2007) and Nwangwu (2007) that the purpose of entrepreneurial curriculum is to equip students with skills that will make them able to create wealth in the era of mass unemployment.

The result in Table 2 indicates that the coefficient of .326 was obtained for the relevance of practical experience gained in the university entrepreneurship training programme to graduates' productivity. The calculated t-value of 10.64 was also obtained which is greater than the critical t-value of 2.04 at 0.05 alpha level. This means that practical experience provided in the university entrepreneurship training programme significantly contributes to graduates' productivity. This confirms the views of Kiod (1977) that students who were involved in practical activities during their learning are more productive than those exposed to only the theoretical aspect of learning.

In Table 3, the result reveals that the coefficient of determination value of 0.648 was obtained. This shows that $64.8 \%$ of the total variation in graduates' productivity was attributed to joint contribution of entrepreneurial contents of university curricula and practical experience acquired in the university entrepreneurship training programme. The F-calculated value of 1104.046 was obtained at 0.05 alpha level; meaning that there is a significant joint contribution of entrepreneurial contents of university curricula and practical experience acquired in the university entrepreneurship training programme to graduates' productivity. This however agrees with Oni in Oladapo and Ike (2010) that Nigerian trained engineers can only be productive, if institutional framework and policy environment are appropriately designed. In other words entrepreneurial contents of university curricula and practical experience acquired in the university entrepreneurship training programme contribute to graduates productivity. 


\section{Conclusions}

On the strength of the findings of this study, conclusions were made that graduates' productivity depends on relevance of the curricula and practical experience given to students undergoing studies. In South South zone of Nigeria, graduates can be more productive if the entrepreneurship education curriculum is improved and more room given to practical work in the universities.

\section{Recommendations}

Based of the findings of this study, the following recommendations are hereby proffered:

1) Nigerian curriculum in the universities should be loaded with more practical work rather than with theories.

2) The curriculum should be more flexible rather than being rigid.

3) The government and National University Commission (NUC) should make it compulsory for faculties offering professional courses to encourage students' participation in practical works.

4) Entrepreneurship Education curriculum should be developed to cater for the vast changing needs of the labour market.

\section{References}

Amaewhale, W. A. (2007). Education, the world of work and the challenge of change: In search of intervention strategies. Inaugural Lecture Series, No. 23; Rivers State University of Science and Technology, Nkpola Port Harcourt.

Ekong, A. O., \& Williams, P. S. (2006). Entrepreneurship education in Nigeria, its implication for manpower needs of the nation. Nigerian Journal of Professional Teachers, 1(3), 112-120.

Etuk, G. K., \& Ekpo, I. V. (2008). Managing education for poverty alleviation and sustainable development in Nigeria. In J. B. Babaloa, G. O. Akpa, I. Hauwa, \& A. O. Ayeni (Eds.), Managing education for sustainable development in developing countries (pp. 49-60). Lagos: National Association for Educational Administration and Planning (NAEAP).

Fluitman, F., \& Haan, H. (2002). Informal sector training: Debates in skills development. World Bank study on vocational skills development in Sub-Saharan-Africa. A working group review (pp. 24-25). Edenburg, Scotland.

Isaac, E., Visser, K., Friedrich, C., \& Brijlal, P. (2007). South African Journal of Education, 27, 612-629.

Kauffman Foundation (2009). Entrepreneurship education. Retrieved March 28, 2009, from $\mathrm{htt} / \mathrm{www}$.google.com

Klod, J. (1977). How adult learn. New York. USA: Association Press.

Kurako, J. F. (2003). Entrepreneurship education: Emerging trends and challenges for the $21^{\text {st }}$ century. Coleman foundation white paper series for the U.S. Association of Small Business and Entrepreneurship. Retrieved September 25, 2006, from http://www.usab.org/pdf/cwp 2003Okuratko.pdf

Madumere-Obike, C. U., \& Abraham, N. M. (2008). Functional and entrepreneurial education at the secondary education section: A veritable tool for poverty alleviation. In J. B. Babaloa, G. O. Akpa, I. Hauwa, \& A. O. Ayeni (Eds.), Managing education for sustainable development in developing countries (pp. 487-495). Lagos: National Association of Educational Administration and Planning (NAEAP).

McClelland, D. C. (1962). Business drive and national achievement. Howard Business Review, 40, 99-112.

Nwangwu, I. O. (2007). Entrepreneurship in education: Concept and constraints. African Journal of Education and Development Studies, 4(1), 196-207.

Oladapo, C., \& Ike, I. (2010). Links between engineering training programmes in tertiary institutions and graduates' productivity in Nigeria. In T. Tchombe, Y. Yaro, D. Troare, \& A. Barry (Eds.), African education development issues, RECARE No.1, 2010 - ISSNa Venir. Abyan: Editions Universities de Cête d'lvoire.

Oluruntoba, S. (2010). Entrepreneurship education crucial to tackling graduates unemployment- Excerpts. Retrieved July 9, 2010, from www.Google.Com.ng

Osuwa, A. A. (2006). Vocational and Technical education for self-actualization and sustainability. Multidisciplinary Journal of Research Development (MULJURED), 7(3), 87-93. 
Peretomode, V. F. (2003). Educational administration: Applied concept and theoretical perspective for students and practitioners. Lagos: Joja Educational Research and Publication Limited.

Rufa, L. R. (2010). Graduate unemployment: NBTE develops entrepreneurial curriculum manuals for polytechnics. The Punch 9-10.

\section{Copyrights}

Copyright for this article is retained by the author(s), with first publication rights granted to the journal.

This is an open-access article distributed under the terms and conditions of the Creative Commons Attribution license (http://creativecommons.org/licenses/by/3.0/). 